Abstracta Iranica Abstracta Iranica

Revue bibliographique pour le domaine irano-aryen

Volume 30 | 2010

Comptes rendus des publications de 2007

\title{
Osțūre-ye Tehrān. Tehrān, Daftar-e pažūheš-hā-ye farhangī, 1385, 250 p.[Le mythe de Téhéran]
}

\section{Bernard Hourcade}

\section{(2) OpenEdition}

1 Journals

\section{Édition électronique}

URL : http://journals.openedition.org/abstractairanica/38200

DOI : 10.4000/abstractairanica.38200

ISSN : 1961-960X

Éditeur :

CNRS (UMR 7528 Mondes iraniens et indiens), Éditions de l'IFRI

\section{Édition imprimée}

Date de publication : 8 avril 2010

ISSN : 0240-8910

\section{Référence électronique}

Bernard Hourcade, «Osțūre-ye Tehrān. Tehrān, Daftar-e pažūheš-hā-ye farhangī, 1385, 250 p. [Le mythe de Téhéran] », Abstracta Iranica [En ligne], Volume 30 | 2010, document 350, mis en ligne le 08 avril 2010, consulté le 03 octobre 2020. URL : http://journals.openedition.org/abstractairanica/38200 ; DOI : https://doi.org/10.4000/abstractairanica.38200

Ce document a été généré automatiquement le 3 octobre 2020.

Tous droits réservés 


\section{Osțūre-ye Tehrān. Tehrān, Daftar-e pažūheš-hā-ye farhangī, 1385, $250 \mathrm{p}$. [Le mythe de Téhéran]}

\section{Bernard Hourcade}

Essai sur la culture, les images et les représentations de la ville de Téhéran dans la culture iranienne ou internationale (romans, films), par une personnalité qui connaît parfaitement la culture de la capitale iranienne. Le mythe de Téhéran est constitué par la réunion paradoxale d'images négatives sur la ville « sans passé », le " non-lieu », sans société complexe, sans culture urbaine, et d'autre part la ville modèle qui attire les ambitieux et donne l'exemple. Une réflexion qui complète judicieusement les analyses de sciences sociales sur la ville iranienne.

\section{INDEX}

Thèmes : 15.1. Iran

\section{AUTEURS}

BERNARD HOURCADE

CNRS/Mondes iranien et indien - Paris 